\title{
Weather relation of rice-grass pea crop sequence in Indian Sundarbans
}

\section{SUKAMAL SARKAR ${ }^{1}$, ARGHA GHOSH ${ }^{2 *}$, KOUSHIK BRAHMACHARI ${ }^{1}$, KRISHNENDU RAY ${ }^{3}$, MANOJ KUMAR NANDA ${ }^{2}$ and DEBOLINA SARKAR ${ }^{2}$}

${ }^{1}$ Department of Agronomy, ${ }^{2}$ Department of Agricultural Meteorology and Physics, Bidhan Chandra Krishi Viswavidyalaya, Mohanpur, Nadia, India;

${ }^{3}$ Sasya Shyamala Krishi Vigyan Kendra, Ramakrishna Mission Vivekananda Educational and Research Institute, Arapanch, Sonarpur, West Bengal, India

*Corresponding author: ghoshargha4@gmail.com

\begin{abstract}
In order to develop weather-based yield prediction models for rice and grass pea in coastal saline zone of West Bengal, the experiments were conducted with rice (cv. CR 1017) and grass pea (cv. Bio $L$ 212) in the rainy and winter seasons, respectively of 2016-17 and 2017-18. Rice was sown in nursery bed on six different dates starting from June 15 to July 19 at weekly interval in both rainy seasons in two different land situations viz. medium upland and medium lowland. Likewise, grass pea was sown on six different dates just before harvesting of rice. It was observed that both early sown rice and grass pea resulted in higher grain yield and took more time to mature under medium lowland situation irrespective of sowing dates. Correlation study revealed that air temperature during sowing to transplanting phase exhibited significant positive correlation with grain of rice in medium upland $\left(\mathrm{T}_{\max }=0.76^{* *}, \mathrm{~T}_{\min }=\right.$ $\left.0.69^{*}\right)$ and medium lowland $\left(T_{\max }=0.93^{* *}, T_{\min }=0.81^{* *}\right)$ situations. On the other hand, maximum temperature and total solar radiation during $100 \%$ emergence to $100 \%$ flowering stage were negatively associated with the grain yield of grass pea in both medium upland $\left(\mathrm{T}_{\max }=-0.69^{*}\right.$, Accumulated solar radiation $\left.=-0.73^{* *}\right)$ and medium lowland $\left(T_{\max }=-0.74^{* *}\right.$, Acc. solar radiation $\left.=-0.77^{* *}\right)$ situations. Grain yield of rice and grass pea could be predicted with $94.4 \%$ and $87.4 \%$ predictability. Pre-harvest forecasting of grain yield was possible with $77.3 \%$ for rice and $83.8 \%$ for grass pea.
\end{abstract}

Keywords: Yield forecasting, date of sowing, pulses, grain yield

Agricultural development in the coastal saline zone (CSZ) of West Bengal is constrained by various physical, chemical and social factors. Apart from the homestead upland, the crop fields of this region are often classified as mediumup, medium-low and lowlands, amongst which later two are usually inundated by floods and rainwater associated with poor drainage. The agriculture of the region is predominantly rainfed and cropping pattern is almost mono-cropped. Only $4 \%$ of the cultivated area of the coastal zone can be irrigated with available sweet water. The region is, therefore, a monocropped area with 4.2 lakh ha cultivated area in the wet season; the lands generally remain fallow for six to seven months in winter and summer (Malik et al., 2016).

Earlysowing, followed by early transplanting enables the rainy season rice to exploit more sunlight days under uninundated field condition resulting in less loss of precious plant nutrients associated with higher photosynthetic activities and ultimately better photosynthate accumulation (Brahmachari et al., 2017). On the other hand, CSZ of West
Bengal is highly affected by variability of rainfall, uncertain dates of onset and recession of monsoon rain which, in turn, restricts cultivation of summer and rainy season rice.

Sowing time is one of the most important factors which determine the yield of crops (Dari et al., 2017; Pradhan et al., 2018). Delay in sowing after the optimum sowing window can have negative effect on crop yield (Ghosh and Khan, 2019; Mallick et al., 2007). Optimization of sowing date of rice under different land situation to utilize residual soil moisture as well as escaping salinity stress for succeeding pulse crops is one of the main mottos of the present experimentation. Grass pea is one of the most important leguminous pulse crops of winter seasons. Due to its quick growing habit, high yielding ability and high adoptability in salt and moisture stress condition (Ghosh, 2018), it may be suitably fitted as a catch crop in the ricebased cropping systems. Keeping these facts in mind, the present experiments were conducted to study the effect of various agro-climatic parameters on yield and to generate 
crop weather relationship for rice and grass pea cropping sequence.

\section{MATERIALS AND METHODS}

Field experiments were conducted in 2016-17 and 2017-18 in the farmer's field of Indian Sundarbans located at Gosaba, South $24 \mathrm{Pgs}$, West Bengal $\left(21.92^{\circ} \mathrm{N}\right.$ latitude and $88.80^{\circ} \mathrm{E}$ longitude with an elevation of $4 \mathrm{~m}$ above mean sea levelto study the weather based yield prediction model for rice and grass pea cropping sequence. Meteorological data during the crop growth period was recorded through Automatic weather station (EM50 Data Collection System, Decagon Inc., Germany) located near the study area. The soil was sandy clay in texture, acidic in reaction ( $\mathrm{pH}$ 5.47) with electrical conductivity $0.89 \mathrm{dS} \mathrm{m}^{\text {"1 }}$ ( soil: water: $1: 5$ ), medium in organic carbon $(0.50 \%)$ and available $\mathrm{K}(133 \mathrm{~kg}$ ha" $\left.{ }^{\prime \prime}\right)$, low in available $\mathrm{P}(15.4 \mathrm{~kg}$ ha" $)$ and high in available $\mathrm{N}(542 \mathrm{~kg} \mathrm{ha"1})$.

The experiment was conducted in strip plot design having two factors namely, Horizontal factor: six dates of sowing of rice (cv. CR 1017) at an interval of one week ( $15^{\text {th }}$ June to $19^{\text {th }}$ July), Vertical factor: Two land situations (Medium-upland and Medium-lowland). Rice seedlings of 22 days old were manually transplanted as per their respective sowing dates, at a spacing of $20 \mathrm{~cm} \times 15 \mathrm{~cm}$ with $3-4$ seedlings per hill. During physiological maturity stage of rice plant, grass pea (cv. Bio-L-212) seeds were sown in the field utilizing the residual soil moisture. All essential nutrient and cultural practices were followed as per the best management practices (Department of Agriculture, GoWB, 2012; Sarangi et al., 2014).

To study the weather based yield prediction models, entire growing season of rice was divided into five distinct growth phases which were sowing to transplanting phase $\left(\mathrm{P}_{\mathrm{R}}-1\right)$, transplanting to panicle initiation phase $\left(\mathrm{P}_{\mathrm{R}}-2\right)$, panicle initiation to $100 \%$ flowering phase $\left(\mathrm{P}_{\mathrm{R}}-3\right), 100 \%$ flowering phase to physiological maturity phase $\left(\mathrm{P}_{\mathrm{R}}-4\right)$ and physiological maturity to harvest $\left(\mathrm{P}_{\mathrm{R}}-5\right)$. On the other hand, growing season of grass pea was divided into four phases namely sowing to $100 \%$ emergence phase $\left(\mathrm{P}_{\mathrm{G}}-1\right), 100 \%$ emergence to $100 \%$ flowering phase $\left(\mathrm{P}_{\mathrm{G}}-2\right), 100 \%$ flowering to physiological maturity $\left(\mathrm{P}_{\mathrm{G}}-3\right)$ and physiological maturity to harvest $\left(\mathrm{P}_{\mathrm{G}}-4\right)$.

Three accumulated agrometeorological indices viz. growing degree day (GDD) occurring at different phases were computed as per Rachaputi et al. (2015). GDD or heat units were computed considering $10^{\circ} \mathrm{C}$ and $5^{\circ} \mathrm{C}$ being the base temperature for development of rice and grass pea, respectively (Ghosh et al., 2018; Rani and Maragatham, 2013).Day length for the latitude of the experimental field where Weather Station was situated was calculated following the table values of possible sunshine hours given by Doorenbos and Pruitt (1977). Photothermal unit (PTU) were calculated using the formulae adopted by Kingra and Kaur (2012). Heat use efficiency (HUE) was obtained by using the formula as suggested by Kinga and Kaur (2012). Photothermal use efficiencies (PTUE) was calculated by formulae adopted from Ghosh et al. (2018). The collected data were analyzed statistically by the analysis of variance (ANOVA) technique using the STAR Software version 2.0.1 (IRRI, 2014). Stepwise regression technique was employed to develop weather-based yield prediction models for both rice and grass pea.

\section{RESULTS AND DISCUSSION}

\section{Effect of sowing dates and land situations on durations of different growth phases}

Durations of different growth phases of rice and grass pea were significantly influenced by the variation in sowing dates (Table 1). In both experimental seasons, effect of sowing dates on duration of growth phases was found to be similar in both medium upland and medium lowland situations. Results revealed that duration of growth phases of both rice and grass pea decreased with delay in sowing dates. It was observed that both rice and grass pea took more time to mature when grown in the medium lowland situation irrespective of sowing dates. In accordance to the present findings, Ghosh and Khan (2019) also reported that with the delay in sowing, duration of grass pea decreased because increased temperature accelerated the developmental rate of the crop.

\section{Variations in agrometeorological parameters}

Crops sown on different dates were exposed to varied weather conditions. During transplanting to panicle initiation stage of rice, as the sowing delayed, total rainfall decreased while accumulated solar radiation increased (Fig. 1 and Fig. 2). On the other hand, total solar radiation, accumulated heat unit and photothermal unit during panicle initiation to $100 \%$ flowering phase and $100 \%$ flowering to maturity phase showed declining trend with delayed sowing. Due to variation in the sowing dates of grass pea, the amount of rainfall, solar radiation, heat unit and photothermal unit accumulated during different growth stages was varying (Fig.1-4). Irrespective of land situations, these similar trends were found in both the experimental years. 
Table 1: Variation in the duration (days) of the growth phases of rice and grass pea as affected by date of sowing grown in different land situations

\begin{tabular}{|c|c|c|c|c|c|c|c|c|c|c|c|c|}
\hline \multicolumn{8}{|c|}{ 2016-17 } & \multicolumn{5}{|c|}{$2017-18$} \\
\hline \multicolumn{13}{|c|}{ Duration of rice growth phase } \\
\hline Date of sowing & $P_{R}-1$ & $\mathrm{P}_{\mathrm{R}}-2$ & $P_{R}-3$ & $\mathrm{P}_{\mathrm{R}}-4$ & $\mathrm{P}_{\mathrm{R}}-5$ & $\begin{array}{l}\text { Total } \\
\text { duration }\end{array}$ & $P_{R}-1$ & $\mathrm{P}_{\mathrm{R}}-2$ & $\mathrm{P}_{\mathrm{R}}-3$ & $\mathrm{P}_{\mathrm{R}}-4$ & $\mathrm{P}_{\mathrm{R}}-5$ & $\begin{array}{l}\text { Total } \\
\text { duration }\end{array}$ \\
\hline \multicolumn{13}{|c|}{ Medium upland } \\
\hline D-1 & 22 & 56 & 34 & 32 & 6 & 150 & 25 & 55 & 32 & 31 & 6 & 149 \\
\hline $\mathrm{D}-2$ & 21 & 56 & 35 & 30 & 7 & 149 & 23 & 58 & 33 & 30 & 4 & 148 \\
\hline D-3 & 21 & 58 & 33 & 28 & 8 & 148 & 21 & 59 & 33 & 28 & 7 & 148 \\
\hline D-4 & 21 & 59 & 31 & 26 & 9 & 146 & 23 & 59 & 31 & 26 & 6 & 145 \\
\hline D-5 & 21 & 57 & 32 & 26 & 9 & 145 & 21 & 60 & 32 & 26 & 4 & 143 \\
\hline D-6 & 21 & 59 & 31 & 25 & 7 & 143 & 25 & 55 & 31 & 25 & 6 & 142 \\
\hline \multicolumn{13}{|c|}{ Medium lowland } \\
\hline D-1 & 22 & 57 & 34 & 33 & 7 & 153 & 25 & 53 & 34 & 33 & 7 & 152 \\
\hline D-2 & 21 & 60 & 35 & 31 & 5 & 152 & 23 & 57 & 35 & 30 & 5 & 150 \\
\hline D-3 & 21 & 59 & 34 & 28 & 8 & 150 & 21 & 62 & 34 & 28 & 6 & 151 \\
\hline D-4 & 21 & 59 & 33 & 28 & 8 & 149 & 23 & 57 & 33 & 28 & 7 & 148 \\
\hline D-5 & 21 & 62 & 32 & 26 & 7 & 148 & 21 & 62 & 32 & 26 & 5 & 146 \\
\hline D-6 & 21 & 59 & 33 & 27 & 7 & 147 & 25 & 55 & 33 & 27 & 4 & 144 \\
\hline \multicolumn{13}{|c|}{ Duration of grass pea growth phase } \\
\hline Date of sowing & $\mathrm{P}_{\mathrm{G}}-1$ & $\mathrm{P}_{\mathrm{G}}-2$ & & $\mathrm{P}_{\mathrm{G}}-3$ & $\mathrm{P}_{\mathrm{G}}-4$ & $\begin{array}{l}\text { Total } \\
\text { duration }\end{array}$ & $P_{G}-1$ & $\mathrm{P}_{\mathrm{G}}-2$ & & $\mathrm{P}_{\mathrm{G}}-3$ & $\mathrm{P}_{\mathrm{G}}-4$ & $\begin{array}{l}\text { Total } \\
\text { duration }\end{array}$ \\
\hline \multicolumn{13}{|c|}{ Medium upland } \\
\hline D-1 & 12 & 65 & & 111 & 6 & 117 & 13 & 68 & & 113 & 6 & 119 \\
\hline $\mathrm{D}-2$ & 11 & 70 & & 108 & 7 & 115 & 12 & 69 & & 110 & 7 & 117 \\
\hline D-3 & 11 & 74 & & 107 & 6 & 113 & 11 & 70 & & 108 & 6 & 114 \\
\hline D-4 & 11 & 70 & & 107 & 5 & 112 & 14 & 69 & & 106 & 6 & 112 \\
\hline D-5 & 11 & 70 & & 105 & 5 & 110 & 14 & 71 & & 104 & 6 & 110 \\
\hline D-6 & 12 & 71 & & 108 & 6 & 114 & 13 & 71 & & 106 & 5 & 111 \\
\hline \multicolumn{13}{|c|}{ Medium lowland } \\
\hline D-1 & 10 & 66 & & 111 & 7 & 118 & 11 & 69 & & 110 & 8 & 118 \\
\hline D-2 & 12 & 69 & & 112 & 7 & 119 & 10 & 69 & & 110 & 7 & 117 \\
\hline D-3 & 12 & 73 & & 107 & 6 & 113 & 11 & 70 & & 108 & 6 & 114 \\
\hline D-4 & 13 & 74 & & 109 & 5 & 114 & 14 & 69 & & 109 & 6 & 115 \\
\hline D-5 & 13 & 73 & & 106 & 6 & 112 & 15 & 71 & & 107 & 6 & 113 \\
\hline D-6 & 15 & 74 & & 108 & 6 & 114 & 14 & 71 & & 108 & 7 & 115 \\
\hline
\end{tabular}



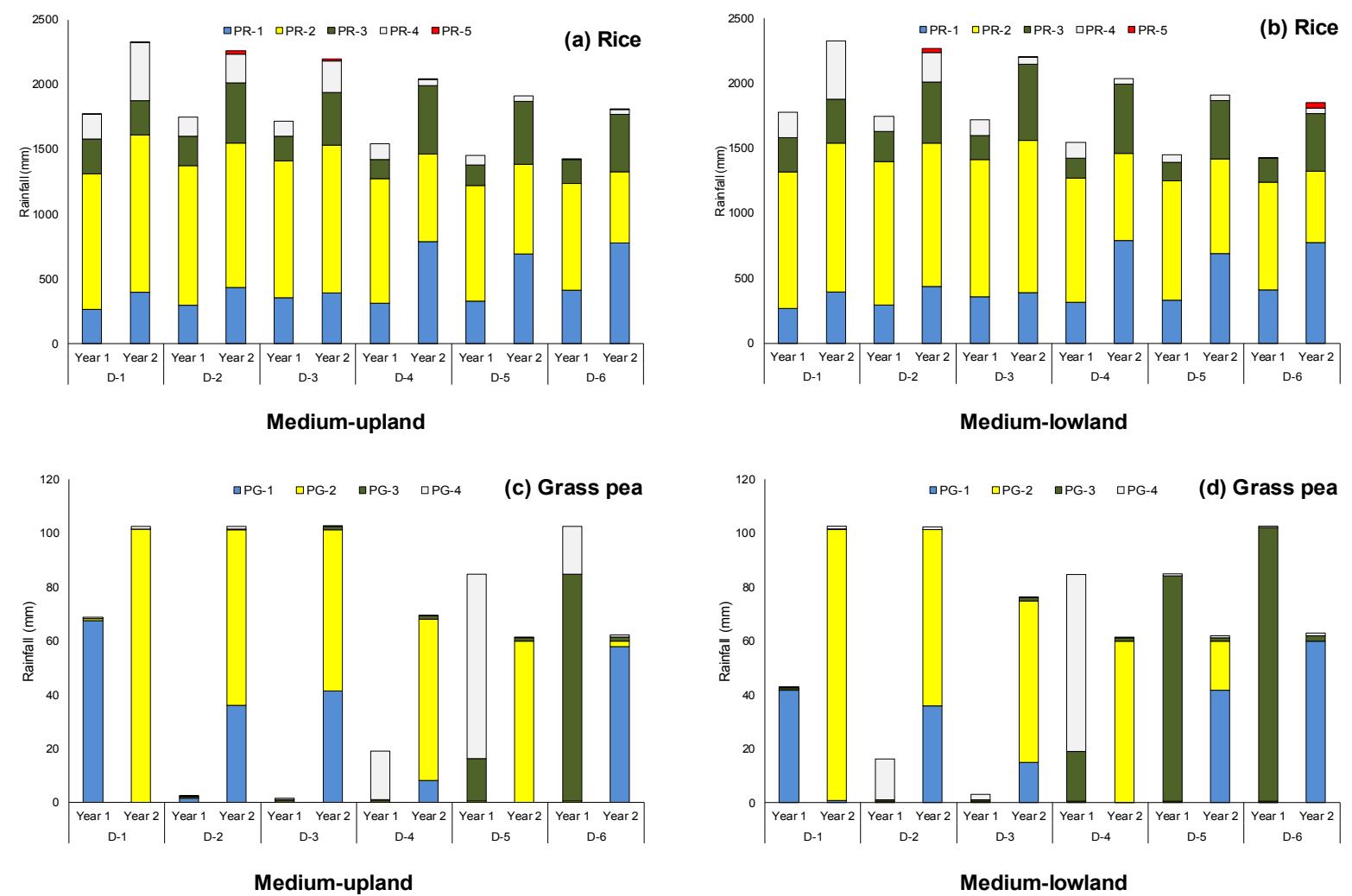

Fig. 1: Phenophase wise distribution of accumulated rainfall in rice (a-b) and grass pea (c-d) growing period grown in different land situation.
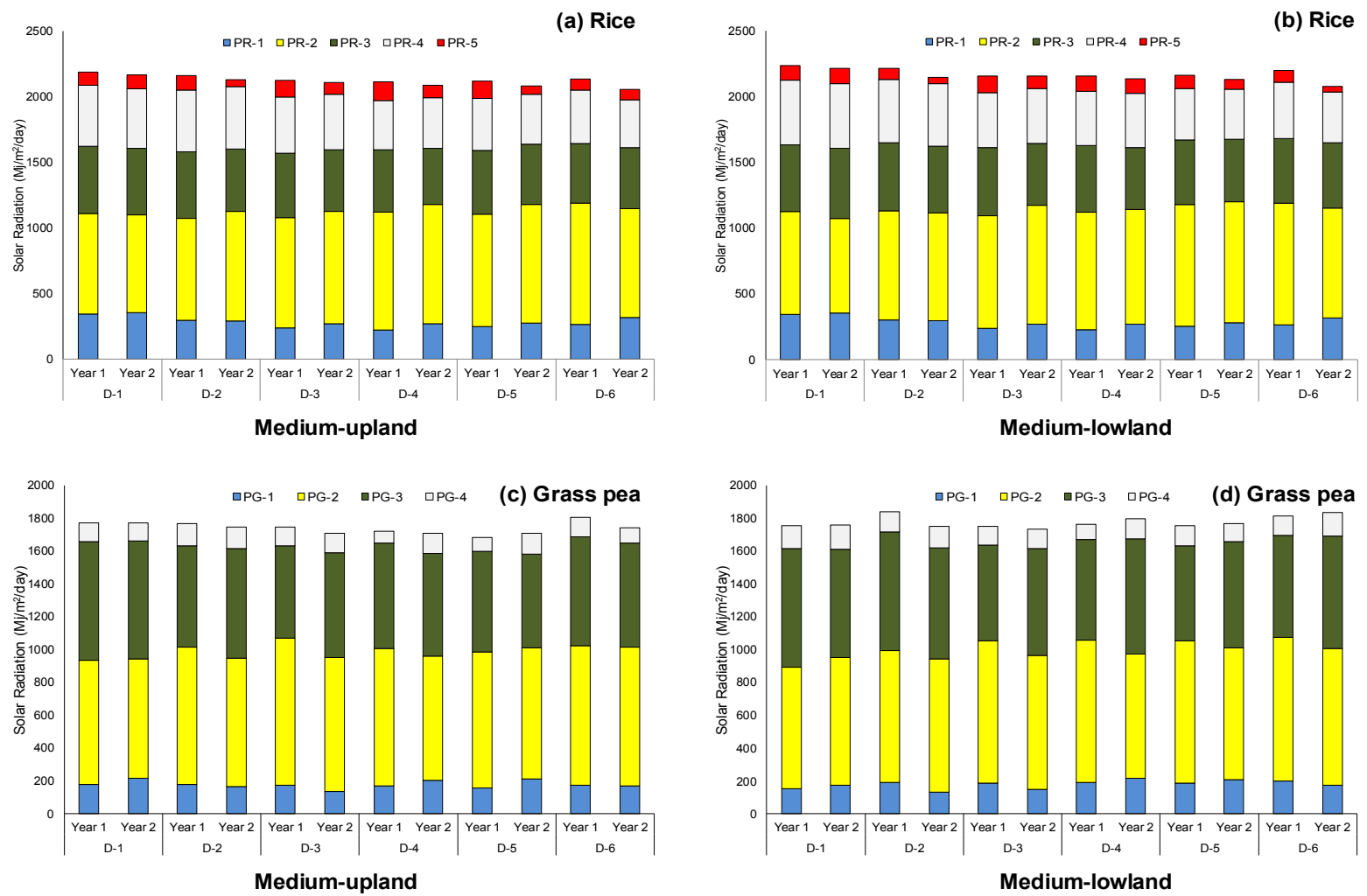

Fig. 2: Phenophase wise distribution of accumulated solar radiation in rice (a-b) and grass pea (c-d) growing period grown in different land situation. 

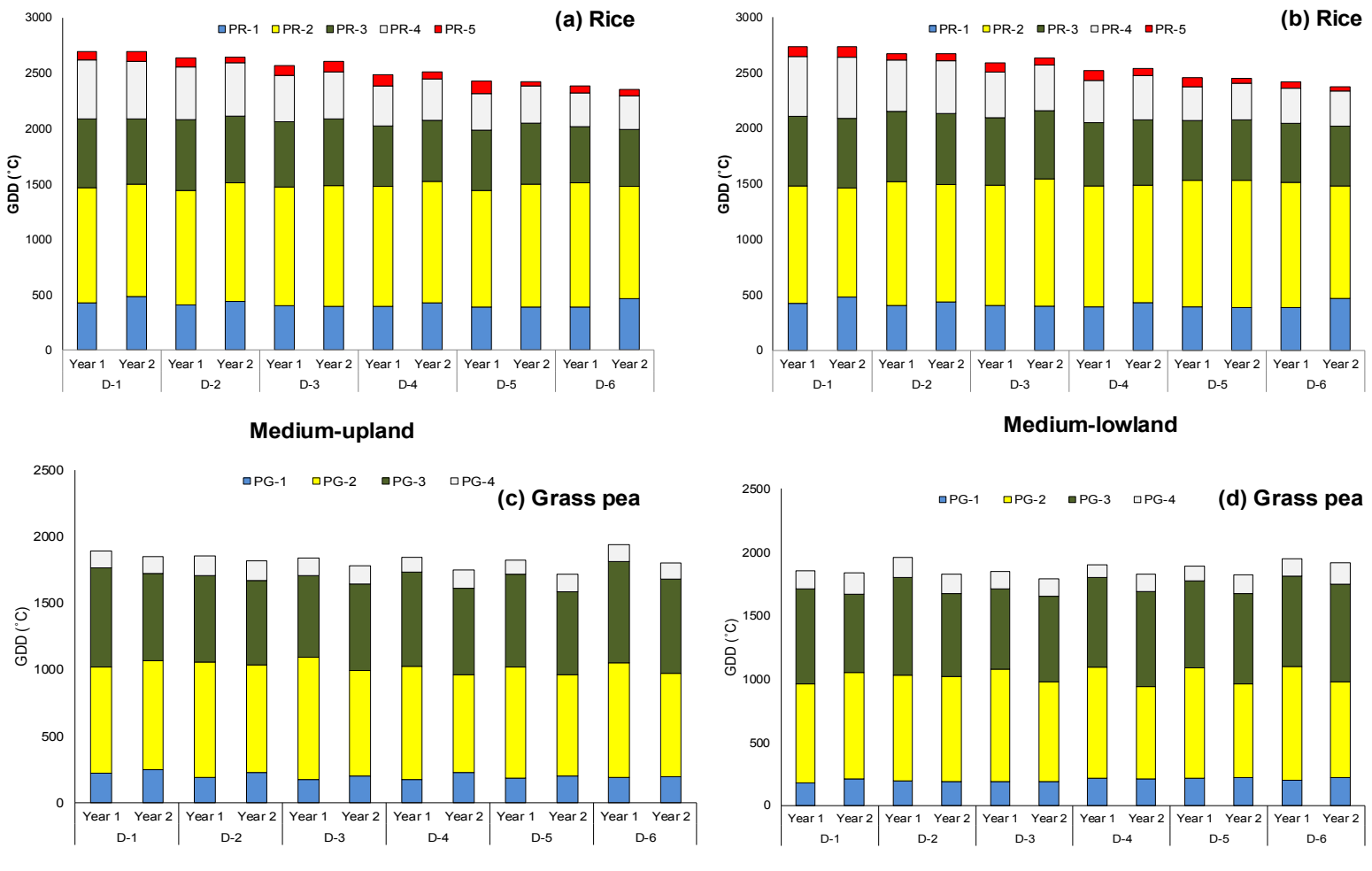

Medium-upland

Medium-lowland

Fig. 3: Pheno-phase wise accumulated GDD in rice (a-b) and grass pea (c-d) growing period grown in different land situation.
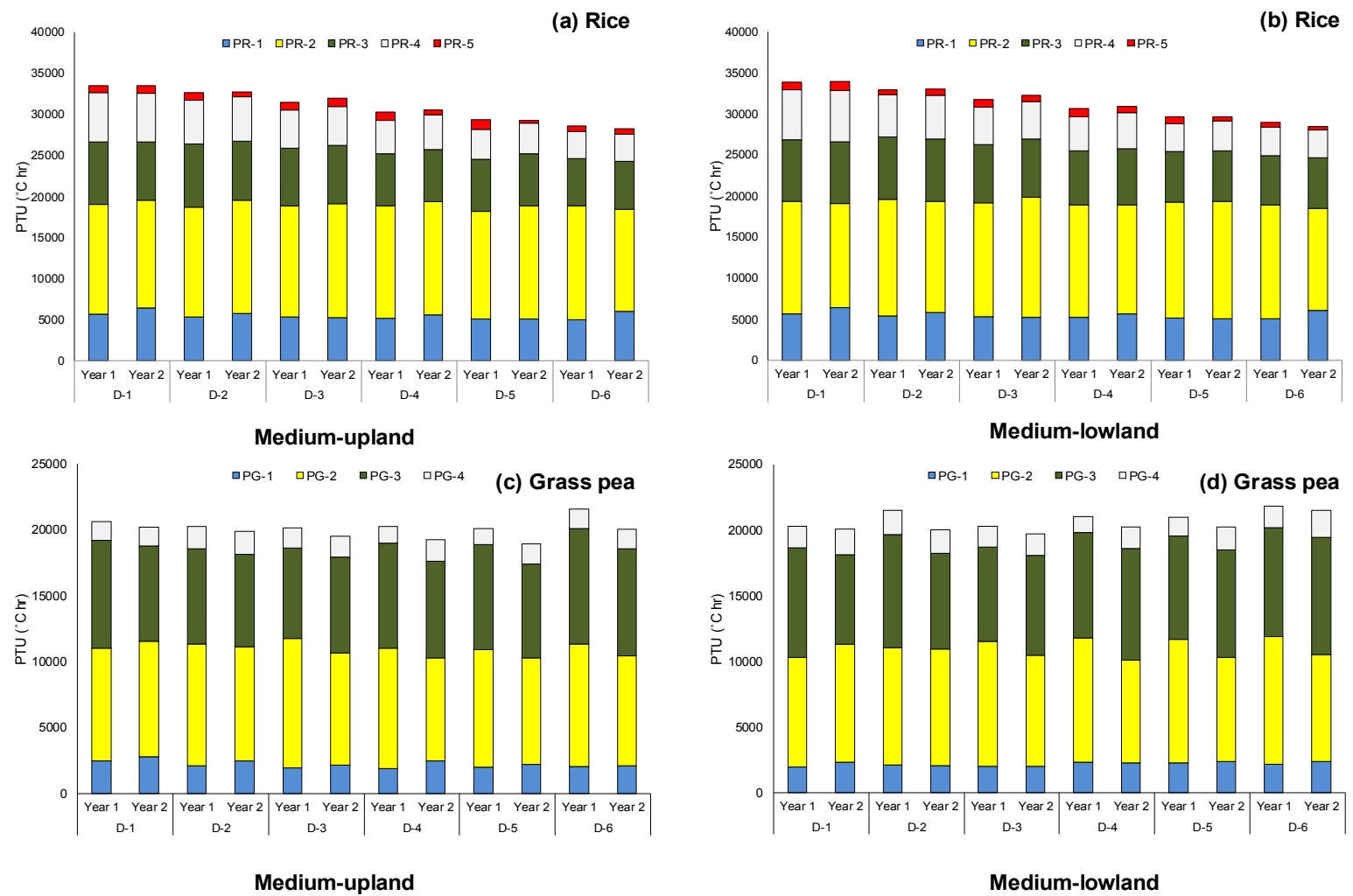

Fig. 4: Phenophase wise accumulated PTU in rice (a-b) and grass pea (c-d) growing period grown in different land situation. 
Table 2: Grain and seed yield of rice and grass pea as influenced by land situation and date of sowing.

\begin{tabular}{lrrrrr}
\hline Treatments & \multicolumn{2}{c}{ Rice grain yield $\left(\mathrm{kg} \mathrm{ha}^{-1}\right)$} & & \multicolumn{2}{c}{ Grass pea seed yield $\left(\mathrm{kg} \mathrm{ha}^{-1}\right)$} \\
\cline { 2 - 3 } \cline { 5 - 5 } Land situation & $2016-17$ & $2017-18$ & & $2016-17$ & $2017-18$ \\
Medium-upland & 4754 & 4782 & & 708.54 & 978.27 \\
Medium-lowland & 5023 & 5005 & & 792.09 & 1026.04 \\
SEm $( \pm)$ & 99.8 & 36.4 & & 4.50 & 5.63 \\
CD $(P$ d"0.05 $)$ & $\mathrm{NS}$ & 163.8 & & 20.27 & 25.32 \\
Date of sowing & & & & \\
D-1 & 5506 & 5385 & & 936.89 & 1192.44 \\
D-2 & 5163 & 5330 & & 819.06 & 1085.00 \\
D-3 & 4925 & 4964 & & 773.13 & 992.75 \\
D-4 & 4844 & 4855 & & 705.00 & 947.63 \\
D-5 & 4513 & 4521 & & 669.06 & 963.88 \\
D-6 & 4381 & 4304 & & 598.75 & 831.25 \\
SEm $( \pm)$ & 109 & 86.1 & & 25.20 & 27.78 \\
CD $(P$ d 0.05 $)$ & 329 & 260 & & 75.95 & 83.74 \\
Land situation $\times$ Date of sowing & NS & NS & NS & NS \\
Date of sowing $\times$ Land situation & NS & NS & NS & NS \\
\hline
\end{tabular}

D-1: $15^{\text {th }}$ June,D-2: $21^{\text {st }}$ June,D-3: $28^{\text {th }}$ June,D-4: $5^{\text {th }}$ July,D-5: $12^{\text {th }}$ July,D-6: $19^{\text {th }}$ July; NS, non-significant

Table 3: Correlation coefficients (r) between yield of rice and grass pea and agrometeorological factors (based on data of Year 1 and Year 2)

\begin{tabular}{|c|c|c|c|c|c|c|c|c|c|c|}
\hline \multirow[t]{3}{*}{ Weather parameters } & \multicolumn{5}{|c|}{ Medium upland } & \multicolumn{5}{|c|}{ Medium lowland } \\
\hline & \multicolumn{10}{|c|}{ Rice } \\
\hline & $\mathrm{P}_{\mathrm{R}}-1$ & $\mathrm{P}_{\mathrm{R}}-2$ & $\mathrm{P}_{\mathrm{R}}-3$ & $\mathrm{P}_{\mathrm{R}}-4$ & $\mathrm{P}_{\mathrm{R}}-5$ & $\mathrm{P}_{\mathrm{R}}-1$ & $\mathrm{P}_{\mathrm{R}}-2$ & $\mathrm{P}_{\mathrm{R}}-3$ & $\mathrm{P}_{\mathrm{R}}-4$ & $\mathrm{P}_{\mathrm{R}}-5$ \\
\hline Accumulate rainfall & -0.45 & $0.76 * *$ & 0.01 & $0.73 * *$ & 0.45 & -0.52 & $0.76 * *$ & 0.04 & $0.75 * *$ & -0.09 \\
\hline Maximum Temperature & $0.76^{* *}$ & -0.21 & $0.81 * *$ & $0.94 * *$ & $0.65^{*}$ & $0.93 * *$ & -0.19 & $0.79 * *$ & $0.95 * *$ & $0.69 *$ \\
\hline Minimum temperature & $0.69 * *$ & $0.66^{*}$ & $0.90 * *$ & $0.95 * *$ & $0.70^{*}$ & $0.81 * *$ & $0.64 *$ & $0.89 * *$ & $0.94 * *$ & $0.62 *$ \\
\hline Relative humidity & $-0.70 * *$ & 0.52 & $0.91 * *$ & $0.89 * *$ & 0.29 & $-0.84 * *$ & 0.46 & $0.87 * *$ & $0.93 * *$ & 0.07 \\
\hline Accumulate solar radiation & 0.33 & -0.55 & 0.45 & $0.79 * *$ & 0.02 & $0.59 *$ & $-0.78 * *$ & 0.54 & $0.91 * *$ & 0.24 \\
\hline Accumulate GDD & 0.30 & -0.21 & $0.79 * *$ & $0.93 * *$ & 0.20 & 0.39 & -0.38 & $0.93 * *$ & $0.98 * *$ & 0.47 \\
\hline Accumulate PTU & 0.39 & 0.29 & $0.83 * *$ & $0.92 * *$ & 0.24 & 0.48 & -0.04 & $0.95 * *$ & $0.98 * *$ & 0.49 \\
\hline \multicolumn{11}{|c|}{ Grass pea } \\
\hline & $\mathrm{P}_{\mathrm{G}}-1$ & $\mathrm{P}_{\mathrm{G}}-2$ & \multicolumn{2}{|c|}{$\mathrm{P}_{\mathrm{G}}-3$} & $\mathrm{P}_{\mathrm{G}}-4$ & $\mathrm{P}_{\mathrm{G}}-1$ & \multicolumn{2}{|l|}{$\mathrm{P}_{\mathrm{G}}-2$} & $\mathrm{P}_{\mathrm{G}}-3$ & $\mathrm{P}_{\mathrm{G}}-4$ \\
\hline Maximum temperature & 0.51 & $-0.69^{*}$ & \multicolumn{2}{|c|}{$-0.88 * *$} & 0.44 & $0.59^{*}$ & \multicolumn{2}{|c|}{$-0.74 * *$} & $-0.85 * *$ & 0.39 \\
\hline Minimum temperature & 0.56 & 0.47 & \multicolumn{2}{|c|}{$-0.77 * *$} & -0.29 & $0.68 *$ & \multicolumn{2}{|l|}{0.39} & $-0.82 * *$ & -0.23 \\
\hline Relative humidity & 0.39 & $0.95 * *$ & \multicolumn{2}{|c|}{$0.93 * *$} & -0.47 & 0.45 & \multicolumn{2}{|c|}{$0.94 * *$} & $0.79 * *$ & $-0.58 *$ \\
\hline Accumulate solar radiation & 0.38 & $-0.73^{*}$ & 0. & & 0.42 & -0.46 & $-0.7^{7}$ & $7 * *$ & 0.50 & 0.55 \\
\hline Accumulate rainfall & 0.25 & $0.88^{*}$ & & $59 *$ & -0.56 & 0.32 & 0.82 & & $-0.68 *$ & -0.36 \\
\hline Accumulate GDD & $0.80 * *$ & -0.48 & & $58 *$ & $0.60^{*}$ & -0.17 & -0.52 & & -0.32 & $0.61 *$ \\
\hline Accumulate PTU & $0.82 * *$ & -0.51 & & $65 *$ & 0.55 & -0.07 & -0.5 & & -0.43 & 0.54 \\
\hline
\end{tabular}


Table 4: Effect of sowing date and land situation on energy use efficiencies of both rice and grass pea

\begin{tabular}{|c|c|c|c|c|c|c|c|}
\hline \multirow[b]{2}{*}{$\begin{array}{l}\text { Land situation } \\
\text { and year }\end{array}$} & \multirow[b]{2}{*}{$\begin{array}{l}\text { Dates of } \\
\text { sowing }\end{array}$} & \multicolumn{3}{|c|}{ Rice } & \multicolumn{3}{|c|}{ Grass pea } \\
\hline & & $\begin{array}{l}\text { RUE } \\
\left(\mathrm{g} \mathrm{MJ}^{-1}\right)\end{array}$ & $\begin{array}{l}\text { HUE } \\
\left(\mathrm{kg} \mathrm{ha}^{-1} \text { day }^{\circ} \mathrm{C}^{-1}\right)\end{array}$ & $\begin{array}{l}\text { PTUE } \\
\left(\mathrm{kg} \mathrm{ha}^{-10} \mathrm{C}^{-1} \text { hour }^{-1}\right)\end{array}$ & $\begin{array}{l}\text { RUE } \\
\left(\mathrm{g} \mathrm{MJ}^{-1}\right)\end{array}$ & $\begin{array}{l}\text { HUE } \\
\left(\mathrm{kg} \mathrm{ha}^{-1} \mathrm{day}^{\circ} \mathrm{C}^{-1}\right)\end{array}$ & $\begin{array}{l}\text { PTUE } \\
\left(\mathrm{kg} \mathrm{ha}^{-10} \mathrm{C}^{-1} \text { hour }^{-1}\right)\end{array}$ \\
\hline Medium upland & D-1 & 0.243 & 1.973 & 0.159 & 0.0048 & 0.453 & 0.041 \\
\hline \multirow[t]{5}{*}{$(2016-17)$} & D-2 & 0.226 & 1.846 & 0.149 & 0.0045 & 0.431 & 0.039 \\
\hline & D-3 & 0.228 & 1.890 & 0.154 & 0.0042 & 0.403 & 0.037 \\
\hline & D-4 & 0.228 & 1.938 & 0.159 & 0.0040 & 0.370 & 0.034 \\
\hline & D-5 & 0.209 & 1.829 & 0.151 & 0.0038 & 0.347 & 0.031 \\
\hline & D-6 & 0.198 & 1.779 & 0.148 & 0.0030 & 0.279 & 0.025 \\
\hline Medium upland & D-1 & 0.241 & 1.939 & 0.156 & 0.0065 & 0.623 & 0.057 \\
\hline \multirow[t]{5}{*}{$(2017-18)$} & D-2 & 0.248 & 1.995 & 0.161 & 0.0063 & 0.602 & 0.055 \\
\hline & D-3 & 0.229 & 1.853 & 0.151 & 0.0056 & 0.538 & 0.049 \\
\hline & D-4 & 0.235 & 1.951 & 0.160 & 0.0054 & 0.531 & 0.048 \\
\hline & D-5 & 0.211 & 1.815 & 0.150 & 0.0055 & 0.545 & 0.049 \\
\hline & D-6 & 0.197 & 1.726 & 0.144 & 0.0046 & 0.444 & 0.040 \\
\hline Medium lowland & D-1 & 0.255 & 2.086 & 0.168 & 0.0058 & 0.549 & 0.050 \\
\hline \multirow[t]{5}{*}{ (2016-17) } & D-2 & 0.246 & 2.041 & 0.165 & 0.0046 & 0.429 & 0.039 \\
\hline & D-3 & 0.232 & 1.933 & 0.158 & 0.0046 & 0.435 & 0.040 \\
\hline & D-4 & 0.226 & 1.934 & 0.159 & 0.0041 & 0.382 & 0.035 \\
\hline & D-5 & 0.212 & 1.867 & 0.155 & 0.0040 & 0.374 & 0.034 \\
\hline & D-6 & 0.206 & 1.871 & 0.156 & 0.0036 & 0.338 & 0.030 \\
\hline Medium lowland & D-1 & 0.250 & 2.024 & 0.163 & 0.0070 & 0.671 & 0.061 \\
\hline \multirow[t]{5}{*}{$(2017-18)$} & D-2 & 0.251 & 2.014 & 0.163 & 0.0061 & 0.589 & 0.054 \\
\hline & D-3 & 0.236 & 1.934 & 0.158 & 0.0059 & 0.575 & 0.052 \\
\hline & D-4 & 0.226 & 1.895 & 0.156 & 0.0054 & 0.528 & 0.048 \\
\hline & D-5 & 0.218 & 1.894 & 0.157 & 0.0056 & 0.545 & 0.049 \\
\hline & D-6 & 0.219 & 1.915 & 0.160 & 0.0047 & 0.450 & 0.040 \\
\hline
\end{tabular}

Year 1 and Year 2 represents winter and rainy seasons of 2016-17 and 2017-18, respectively.

Effect of date of sowing and land situation on yield of rice and grass pea

Data presented in Table 2 revealed that, in both experimental years, the date of sowing significantly influenced the grain yield of rice and grass pea except Year 2. Irrespective of land situations, crop sown on $1^{\text {st }}$ and $2^{\text {nd }}$ dates recorded significantly higher grain. From the Table 3 , it was quite clear that crop grown under medium-low land condition performed better than that grown under mediumupland condition. Interaction between date of sowing and land situation did not have significant impact on yield of rice.
Date of sowing of rice and land situation significantly $(P<0.05)$ influenced the yield of grass pea (Table 2$)$. Irrespective of land situations, grass pea sown on $1^{\text {st }}$ to $2^{\text {nd }}$ dates recorded significantly higher grain. On the other hand, crop sown on medium-lowland situation recorded higher seed yield than that sown on medium-upland condition. Interaction effect of date of sowing and land situation had non-significant impact on yield of grass pea. The performance of grass pea was significantly better in 2017-18 as compared to 2016-17. It may be due to the congenial weather, good agronomic management or less salt accumulation in root zone. But in both the years, crop sown on early dates performed better than late sown crops. 
Table 5: Regression equations involving agroclimatic parameters to predict grain yield and biological yield of rice and grass pea (based on data of Two Years).

\begin{tabular}{|c|c|c|c|c|c|}
\hline Yield & Model & Regression equations & Adjusted $\mathrm{R}^{2}$ & $\begin{array}{l}\text { Standard } \\
\text { error of } \\
\text { estimates }\end{array}$ & $\begin{array}{r}\text { Rate of } \\
\text { increment } \\
\text { in } \mathrm{R}^{2}\end{array}$ \\
\hline Rice & 2 & $Y=-128.784+6.493 R_{1}+2.8 R_{2}$ & $0.880 * *$ & 146.28 & 0.051 \\
\hline \multirow[t]{3}{*}{ Grass pea } & 1 & $\mathrm{Y}=-1737.05+37.567 \mathrm{G}_{1}$ & $0.785 * *$ & 81.60 & \\
\hline & 2 & $\mathrm{Y}=-1997.51+25.575 \mathrm{G}_{1}+19.852 \mathrm{G}_{2}$ & $0.840 * *$ & 70.46 & 0.055 \\
\hline & 3 & $\mathrm{Y}=-2023+23.525 \mathrm{G}_{1}+17.682 \mathrm{G}_{2}+0.181 \mathrm{G}_{3}$ & $0.874 * *$ & 62.63 & 0.034 \\
\hline
\end{tabular}

$\mathrm{R}_{1}=$ relative humidity during $100 \%$ emergence to $100 \%$ flowering phase of rice; $\mathrm{R}_{2}=$ relative humidity during $100 \%$ flowering to maturity phase of rice; $\mathrm{R}_{3}=$ accumulated PTU during maturity to harvest of rice; $\mathrm{R}_{4}=$ accumulated solar radiation during maturity to harvest of rice; $\mathrm{G}_{1}=$ relative humidity during $100 \%$ emergence to $100 \%$ flowering phase of grass pea; $\mathrm{G}_{2}=$ relative humidity during $100 \%$ flowering to maturity phase of grass pea; $\mathrm{G}_{3}=$ accumulated PTU during maturity to harvest phase of grass pea; $\mathrm{G}_{4}=$ accumulated solar radiation during maturity to harvest phase of grass pea; ** indicates significant at $p \leq 0.01$.

Table 6: Regression equations involving agroclimatic parameters for pre-harvest forecasting of grain yield of rice and grass pea (based on mean data of Two Years).

\begin{tabular}{|c|c|c|c|c|}
\hline Crop & Model & Regression equations & Adjusted $\mathrm{R}^{2}$ & $\begin{array}{r}\text { Standard error of } \\
\text { estimates }\end{array}$ \\
\hline Rice & 1 & $\mathrm{Y}=838.372+0.597 \mathrm{X}_{1}$ & $0.773 * *$ & 201.55 \\
\hline \multirow[t]{2}{*}{ Grass pea } & 1 & $Y=-1737.05+37.567 X_{2}$ & $0.785 * *$ & 81.60 \\
\hline & 2 & $Y=-1014.66+26.486 X_{2}+1.765 X_{3}$ & $0.838 * *$ & 70.84 \\
\hline
\end{tabular}

$\mathrm{X}_{1}=$ accumulated PTU during panicle initiation to $100 \%$ flowering phase of rice; $\mathrm{X}_{2}=$ relative humidity during $100 \%$ emergence to $100 \%$ flowering phase of grass pea; $\mathrm{X}_{3}=$ accumulated rainfall during $100 \%$ emergence to $100 \%$ flowering phase of grass pea; $* *$ indicates significant at $p \leq 0.01$

Optimum sowing time is one of the most significant factors determining the crop yield. Previous researchers have reported that delay in sowing of rice beyond the optimum sowing window can have negative effect on crop yield (Pal et al., 2017). In the present experiment, early sown rice performed better than latter sown crops in terms of grain. This may be due to higher remobilization of resources in the early sown crop which probably was linked to the higher dry matter of the crop at anthesis, thus representing the potential source for dry matter remobilization (Pal et al., 2017). Agrometrological factors like air temperature, solar radiation and seasonal destitution of rainfall also plays significant role to determine the yield of rainy season rice (Huang et al., 2019). On the other hand, early sown crop helped to vacate the field early for the succeeding rabi crops. Early sown rice has significant yield advantages for the relay sown pulse crops by better utilization of soil moisture (Kar and Kumar, 2009) and post-monsoon salinity stress (Malik et al., 2016).

\section{Effect of weather parameters on yield of rice and grass pea}

In order to determine the effect of weather parameters on grain yield of rice, correlation study was carried out and the values of correlation coefficient $(r)$ were presented in Table 3. Air temperature during sowing to transplanting phase exhibited significant positive correlation with grain yield of rice in medium upland $\left(\mathrm{T}_{\max }=0.76^{* *}, \mathrm{~T}_{\min }=0.69^{*}\right)$ and medium lowland $\left(\mathrm{T}_{\max }=0.93^{* *}, \mathrm{~T}_{\min }=0.81^{* *}\right)$ situations. During panicle initiation to $100 \%$ flowering stage and $100 \%$ flowering to physiological maturity stage all agrometeorological parameters (mean and accumulated) exhibited beneficial impacts on the production of grain yield irrespective of two land situations.

Table 3 represents the correlation coefficient values between agrometeorological factors and yield of grass pea 
grown under two different land situations. Results revealed that the maximum temperature and total solar radiation during $100 \%$ emergence to $100 \%$ flowering stage were negatively associated with the seed yield of grass pea in both medium upland $\left(\mathrm{T}_{\max }=-0.69^{*}\right.$, Acc. solar radiation $=$ $\left.0.73^{* *}\right)$ and medium lowland $\left(\mathrm{T}_{\max }=-0.74^{* *}\right.$, Acc. solar radiation $=-0.77^{* *}$ ) situations. Relative humidity and total rainfall during $100 \%$ emergence to $100 \%$ flowering stage showed beneficial effect on grain yield of grass pea as demonstrated by positive values of $r$. Maximum and minimum air temperatures prevailing during the $100 \%$ flowering to maturity stage adversely affected grass pea yield in both medium upland $\left(\mathrm{T}_{\max }=-0.88^{* *}, \mathrm{~T}_{\min }=-0.77^{* *}\right)$ and medium low land $\left(\mathrm{T}_{\max }=-0.85^{* *}, \mathrm{~T}_{\min }=-0.82^{* *}\right)$ situations. Grain yield of grass pea decreased as the sowing delayed which may be attributed due to the adverse effect of temperature during the reproductive stage of the crop. The crops sown on later date experienced higher temperature during flowering phase which caused floral abortion and produced lesser numbers of pods (Ghosh, 2018). Increased temperature had negative effect on pod filling (Ghosh and Khan, 2018) which ultimately reduced grain yield.

\section{Effect of sowing date and land situation on energy use efficiencies}

Energy use efficiencies of the crops were determined in terms of radiation use efficiency $\left(\mathrm{g} \mathrm{MJ}^{-1}\right)$, heat use efficiency $\left(\mathrm{kg} \mathrm{day}^{-1} \mathrm{C}^{-1}\right)$ and photothermal use efficiency $\left(\mathrm{kg}{ }^{\circ} \mathrm{C}^{-1}\right.$ hour $\left.{ }^{-1}\right)$. In both the years, all the energy use efficiencies showed declining trend as sowing delayed (Table 4) for both rice and grass pea. In case of rice it was found that the crop grown in medium lowland situation was more efficient to utilize radiation, heat unit and photothermal units as demonstrated by the higher values of use efficiencies. Similar trend was observed for grass pea in both the years.

\section{Yield prediction of rice and grass pea}

Stepwise linear regression models were used to predict grain yield of both rice and grass pea using meteorological factors as explanatory variables. It was found that grain yield of rice could be predicted by four models with very good predictability (Table 5). Model $1\left(\mathrm{R}^{2}=0.829^{* *}\right)$ involved accumulated GDD during 100\% flowering to maturity phase and predicted grain yield with $82.9 \%$ predictability. Model 2 added accumulated solar radiation during transplanting to panicle initiation phase to model 1 and resulted in a predictability of $88.0 \%$. Likewise, model 3 $\left(\mathrm{R}^{2}=0.916^{* *}\right)$ and model $4\left(\mathrm{R}^{2}=0.944 * *\right)$ included accumulated solar radiation during panicle initiation to 100
$\%$ flowering phase and accumulated GDD during sowing to transplanting phase respectively in the linear model. It was evident that accumulated heat unit and solar radiation were the main driving factors for grain production of rice.

Three models were estimated in order to forecast the grain yield of grass pea (Table 4). Relative humidity during $100 \%$ emergence to $100 \%$ flowering phase were selected by the regression technique to predict grain $\left(\mathrm{R}^{2}=0.785^{* *}\right)$. Inclusion of relative humidity during $100 \%$ flowering to maturity phase in the model 1 demonstrated $84.0 \%$ of the total variability in grain yield of grass pea through linear regression equation (model 2). Model 3 involved accumulated PTU during maturity to harvest phase over model 2 and predicted grain yield with $87.4 \%$ predictability. Agrometeorological factors were effectively used for predicting grain yield of grass pea which agreed with the results found by Ghosh (2018)

\section{Pre-harvest forecasting of yield}

In order to forecast the yield of the two crops step wise regression analysis was employed involving the agrometeorological factors prevailing during sowing to $100 \%$ flowering of both rice and grass pea (Table 6). Results gave only one model for predicting grain yield of rice using accumulated PTU during panicle initiation to $100 \%$ flowering phase $\left(\mathrm{R}^{2}=0.773^{* *}\right)$. On the other hand, two models were obtained for pre harvest forecasting of grain yield of grass pea with $78.5 \%$ and $83.8 \%$ predictability, respectively. It was observed that relative humidity and accumulated rainfall during $100 \%$ emergence to $100 \%$ flowering phase were able to predict grain yield of grass pea before harvest.

\section{CONCLUSION}

From the two year study it is evident that both rice and grass pea took more time to mature when cultivated in the medium lowland situation (compared to medium upland) irrespective of sowing dates. It was observed that rice and grass pea produced lesser grain yield if the sowing was delayed. Better productions were obtained from medium lowland situations in case of both rice and grass pea. Agrometeorological parameters prevailing during crop growing season affected durations of growth phases and yield. Solar radiation and heat unit accumulated during panicle initiation to physiological maturity phase were proved to be the most crucial factors for determining yield of rice.

\section{ACKNOWLEDGEMENT}

The study is funded by the Australian Centre for 
International Agricultural Research through the project 'Cropping system intensification in the salt-affected coastal zones of Bangladesh and West Bengal India' (LWR/2014/ 073).

\section{REFERENCES}

Brahmachari, K., Sarkar, S. and Burman, D. (2017). Cropping System Intensification under salt affected coastal areas of West Bengal. In Proceedings: ISCAR Seminar on "Coastal Ecosystem of India-recent development and future strategies. pp. 57-60.

Dari, B., Sihi, D., Bal, S.K. and Kunwar, S. (2017). Performance of direct-seeded rice under various dates of sowing and irrigation regimes in semi-arid region of India. Paddy Water Environ., 15: 395-401.

Doorenbos, J. and Pruitt, W.O. (1977) Crop Water Requirements. FAO Irrigation and Drainage Paper24, FAO, Rome, 144 p.

Ghosh, A. (2018). Assessing the impact of agro-climatic factors on pod filling of grass pea. Legum. Res. - An Int. J. https:/ /doi.org/10.18805/LR-4008

Ghosh,A. and Khan, S.A. (2018). Determination of Optimum Sowing Time of Grass Pea Based on Yield Variation as Affected byVaried Dates of Sowing in New Alluvial Zone of West Bengal. Int. J. Agric. Environ. Biotechnol., 11: $11-16$.

Ghosh, A. and Khan, S.A. (2019). Study on the Interactions Between Lathyrus (Lathyrus sativus L.) and Agroclimatic Factors to Generate Weather Based Yield Forecasting Models. Int.J. Bio-resource Stress Manage., 10: $157-165$.

Ghosh, A., Malo, M. and Khan, S.A. (2018). Impact of Sowing Time on Thermal Utilization of Grass Pea in NewAlluvial Zone of West Bengal. Int. J. Pure App. Biosci., 6: 272278.

Govt. ofWest Bengal. Statistics Division. (2014). Department of Agriculture \& Cooperation, Government of India. [Data accessed on 1st August, 2016].

Huang, M., Fang, S., Shan, S. and Zou, Y. (2019). Delayed transplanting reduced grain yield due to low temperature stress at anthesis in machine-transplanted late-season rice. Exp. Agric., 1-6.
IRRI. (2014). Statistical Tool for Agricultural Research, Version 2.0.1. In: User's Manual. Biometrics and Breeding Informatics, PBGB, Division. International Rice Research Institute, Los Bãnos, Philippines.

Kar, G. and Kumar,A. (2009). Evaluation of post-rainy season crops with residual soil moisture and different tillage methods in rice fallow of eastern India. Agric. Water Manage., 96: 931-938

Kinga, P. and Kaur, P. (2012). Effect of Dates of Sowing on Thermal Utilisation and Heat Use Efficiency of Groundnut Cultivars in Central Punjab. J. Agric. Phy., 12:1-12.

Malik, A.I.,Ali, M.O.,Zaman, M.S., Flower, K., Rahman, M.M. and Erskine, W. (2016). Relay sowing of lentil (Lens culinaris subsp. culinaris) to intensify rice-based cropping. J. Agric. Sci., 154: 850-857.

Mallick, K., Mukherjee, J., Bal, S.K., Bhalla, S.S. and Hundal, S.S. (2007). Real time rice yield forecasting over central Punjab region using crop weather regression model. $J$. Agrometeorol., 9(2): 158-166.

Pal, R., Mahajan, G., Sardana, V. and Chauhan, B.S. (2017). Impact of sowing date on yield, dry matter and nitrogen accumulation, and nitrogen translocation in dry-seeded rice in North-West India. For. Crop. Res., 206: 138-148.

Pradhan, A., Nag, S.K. and Mukherjee, S.C. (2018). Thermal requirement of small millets in Chhattisgarh plateau under rainfed cropping situation. J . Agrometeorol., 20(3): 244-245.

Rachaputi, R.C.N., Chauhan, Y., Douglas, C., Martin, W., Krosch, S., Agius, P. and King, K. (2015). Physiological basis of yield variation in response to row spacing and plant densityof mungbean grown in subtropical environments. Field Crop. Res., 183: 14-22.

Rani, B.A. and Maragatham, N. (2013). Effect of elevated temperature on rice phenology and yield. Ind. J. Sci. Technol., 6: 5095-5097.

Sarangi, S.K., Maji, B., Singh, S., Sharma, D.K., Burman, D., Mandal, S., Ismail,A.M. and Haefele, S.M. (2014). Crop Establishment and Nutrient Management for Dry Season (Boro) Rice in Coastal Areas. Agron. J., 106: 2013. 